\title{
PEMASARAN ONLINE ANEKA OLAHAN MAKANAN DI DESA JENDI,
} SELOGIRI, WONOGIRI

\author{
Irsyadul Ibad, Susilaningsih \\ Pusat Pengembangan Kewirausahaan LPPM Universitas Sebelas Maret, Jl. Ir. Sutami No.36A, \\ Surakarta, 57126, Indonesia. \\ Email: doelibad@gmail.com
}

\begin{abstract}
Abstrak
Salah satu kendala pengembangan produk UKM di Desa Jendi adalah kesulitan dalam menjual produknya. Sebagian besar pelaku UKM hanya menjual produknya secara langsung di sekitar tempat usahanya padahal perkembangan teknologi internet dan sosial media telah menciptakan peluang besar bagi pemasaran produk UKM. Perkembangan teknologi tersebut memungkinkan pelaku UKM untuk dapat memasarkan produknya dengan jaringan yang lebih luas namun dengan biaya yang minimal. Tetapi, masih banyak pelaku UKM yang belum mengetahui bagaimana pemasaran online melalui internet dan sosial media. Hasil penelitian terdahulu mengenai sosial media ternyata memberikan pengaruh bagi perilaku konsumsi masyarakat. Metode yang digunakan adalah melalui peningkatan kapasitas sumber daya manusia dalam mengelola website dan sosial media. Tahapan kegiatan pengabdian ini adalah sebagai berikut: analisis kebutuhan dalam perencanaan program, pengembangan kapasitas internal kelembagaan khususnya pada Kelompok Kerja UKM meliputi; kegiatan peningkatan pengetahuan manajemen pemasaran, peningkatan pengetahuan dan ketrampilan teknis pengelolaan website dan social media, peningkatan softskill penulisan konten website dan social media. Ketiga dengan pengembangan jejaring pemasaran dengan stakeholders terkait. Hasil yang telah dicapai pada kegiatan ini antara lain koordinasi awal kegiatan, pelatihan inclass dan pemberian kamera sebagai alat penunjang pemasaran.

Kata Kunci: UKM, Pemasaran, Online, Internet, Social Media
\end{abstract}

\section{Abstract}

One of the challenges of developing SME products in Jendi is the difficulty in selling their products. Most SME entrepreneurs only sell their products directly around their place even though the development of internet technology and social media has created great opportunities for SME product marketing. These technological developments increase SMEs to be able to market their products with a wider network with minimal costs. However, there are still many who support SMEs that do not yet know how to market online through the internet and social media. Previous results of research on social media turned out to provide information about community consumption. The method used is through increasing the capacity of human resources 
in managing websites and social media. The stages of this service activity are as follows: Analysis of needs in program planning, Development of internal capacity Activities Increased knowledge of marketing management, Increased knowledge and technical skills in managing websites and social media, Increased soft skills improve website content and social media. The third is the development of a marketing network with relevant stakeholders. The results agreed upon in this activity were among others the initial coordination of activities, in-class training and camera providers as marketing support tools.

Keywords: SMEs, Marketing, Online, Internet, Social Media

\section{PENDAHULUAN}

Desa memiliki potensi yang dapat menjadi faktor pendukung dalam pembangunan suatu negara. Adanya potensi tersebut perlu didukung dengan kemampuan desa dalam memanfaatkan sumber dayanya untuk mengoptimalkan pendapatan masyarakat. Salah satu potensi di desa adalah pengembangan usaha kecil menengah (UKM). Untuk mendorong pengembangan tersebut maka kapasitas sumber daya manusia di desa menjadi perhatian utama. Dampak jangka panjangnya adalah kemandirian masyarakat desa dari sisi keahlian dan finansial.

Salah satu kendala
pengembangan produk UKM di desa adalah kesulitan dalam menjual produknya. Sebagian besar pelaku UKM hanya menjual produknya secara langsung di sekitar tempat usahanya padahal perkembangan teknologi internet dan sosial media telah menciptakan peluang besar bagi pemasaran produk UKM. Perkembangan teknologi tersebut memungkinkan pelaku UKM untuk dapat memasarkan produknya dengan jaringan yang lebih luas namun dengan biaya yang minimal. Tetapi, masih banyak pelaku UKM yang belum mengetahui bagaimana pemasaran online melalui internet dan sosial media. Hasil penelitian terdahulu mengenai sosial media ternyata memberikan pengaruh bagi perilaku konsumsi masyarakat. Internet dan sosial media menyebarkan informasi dengan cepat dan tanpa batas. Social media memberikan ruang bagi penggunanya untuk berinteraksi dengan pengguna yang lain (Hajli, 2014).

Di Kabupeten Wonogiri, desa Jendi khususnya ibu-ibu yang tergabung dalam LPKK Putri Mandiri merupakan sentra usaha kuliner berbahan baku lokal. Pengembangan website dan sosial media desa menjadi kebutuhan jangka pendek bagi Desa Jendi untuk promosi produknya dikarenakan belum ada sama sekali media online yang digunakan untuk mendukung pemasaran produk usahanya.

Pusat

Pengembangan

Kewirausahaan telah melakukan pembinaan terhadap LPKK Putri Mandiri mulai tahun 2012 melalui program CSR bekerjasama dengan PT. Alexis. Pada tahun 2012 hingga 2014 pembinaan lebih di intensifkan terhadap pembentukan pengurus dan organisasi LPKK Putri Mandiri. Pada tahun 2015, kegiatan pendampingan ditekankan terhadap pembuatan produk aneka olahan makanan yang berkualitas. Di tahun 2015 ini 
beberapa olahan makanan yang diproduksi antara lain: keripik pisang, keripik tempe, gethuk lindri dan goreng, sari kacang hijau, onde-onde, keripik jamur dan beberapa makanan lainnya. Sedangkan di tahun 2016 kegiatan pendampingan difokuskan kepada pengemasan. Produk-produk olahan makanan dikemas menggunakan kardus, sedangkan produk minuman dikemas menggunakan cup sealer. Selain itu, tim juga memberikan bantuan TTG berupa hand sealer dan spinner.
Disisi lain, Desa Jendi Wonogiri juga memiliki kelompok Karang Taruna yang berisi muda-mudi yang masih sekolah maupun yang telah lulus sekolah tetapi tidak memiliki pekerjaan. Dengan adanya kegiatan ini, para pemuda-pemudi Karang Taruuna akan diberikan pelatihan mengenai pemasaran online. Mereka akan menjual berbagai macam olahan makanan produksi. Diharapkan melalui kegiatan ini, tingkat pengangguran di Desa Jendi dapat di kurangi dan meningkatkan kesejahteraan masyarakat.

\section{METODE}

Tabel 1. Metode Kegiatan

\begin{tabular}{|c|c|c|c|}
\hline No & Pendekatan & Kegiatan & Partisipan \\
\hline 1 & Analisis Kebutuhan & Perencanaan program & $\begin{array}{l}\text { Tim pengabdian } \\
\text { UNS dan } \\
\text { kelembagaan desa } \\
\text { Jendi }\end{array}$ \\
\hline 2 & $\begin{array}{l}\text { Pengembangan } \\
\text { kapasitas internal } \\
\text { Kelompok Kerja } \\
\text { UKM }\end{array}$ & $\begin{array}{l}\text { Kegiatan peningkatan } \\
\text { pengetahuan manajemen } \\
\text { pemasaran, peningkatan } \\
\text { pengetahuan dan } \\
\text { ketrampilan teknis } \\
\text { pengelolaan website dan } \\
\text { social media, } \\
\text { peningkatan softskill } \\
\text { penulisan konten website } \\
\text { dan social media }\end{array}$ & $\begin{array}{l}\text { Kelompok Kerja } \\
\text { UKM Desa Jendi }\end{array}$ \\
\hline 3 & $\begin{array}{l}\text { pengembangan } \\
\text { jejaring pemasaran }\end{array}$ & $\begin{array}{l}\text { Pengembangan jejaring } \\
\text { pemasaran dengan } \\
\text { stakeholders UKM }\end{array}$ & $\begin{array}{l}\text { Desa Jendi dengan } \\
\text { Dinas Koperasi dan } \\
\text { UMKM Kabupaten } \\
\text { Wonogiri dan } \\
\text { Dinas Perindustrian } \\
\text { Kabupaten } \\
\text { Wonogiri. }\end{array}$ \\
\hline 4 & Monev & Evaluasi hasil PKM & $\begin{array}{l}\text { Tim pengabdian } \\
\text { UNS }\end{array}$ \\
\hline
\end{tabular}




\section{HASIL DAN PEMBAHASAN}

1. Koordinasi awal kegiatan

Koordinasi dilakukan di Desa Jendi, Selogiri, Wonogiri. Pada koordinasi ini juga dilakukan monitoring keberhasilan pendampingan tahun-tahun sebelumnya. Hasil dari koordinasi ini antara lain:

a) Getuk sudah tidak diproduksi lagi karena salah satu anggota keluarga sakit sehingga tidak ada waktu memproduksi getuk.

b) Usaha keripik jamur, keripik tempe dan jamu herbal masih berjalan hingga saat ini namun masih terdapat kendala pada packaging keripik jamur dan keripik tempe yang kurang menarik.

c) Pemasaran baru dilakukan di toko-toko kelontong dan saat ada permintaan atau pesanan dari pelanggan.

d) Langkah yang dapat diambil dalam pendampingan ini adalah memulai untuk melakukan pemasaran secara online antara lain dengan membuat website, toko online (tokopedia, lazada, bukalapak, dll), serta social media (instagram, facebook, dll).

e) Memberikan bantuan kemasan untuk usaha keripik jamur dan usaha keripik tempe. Untuk usaha jamu herbal, kemasan masih bagus karna tahun 2016 tim PPKwu telah memberikan bantuan berupa cup sealer dan sticker yang masih digunakan hingga saat ini.

f) Memberikan bantuan berupa kamera untuk menunjang pemasaran online.

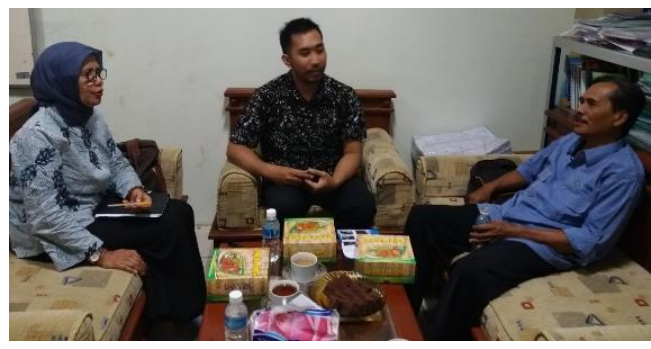

Gambar 1. Koordinasi kegiatan

2. Pelatihan inclass

Pelatihan inclass diberikan kepada LPKK Putri Mandiri dan Karang Taruna yang ada di Desa Jendi, Kecamatan Selogiri, Kabupaten Wonogiri. Materi pelatihan yang diberikan adalah pemasaran offline dan pemasaran online. Materi diberikan oleh tim pelaksana serta narasumber.

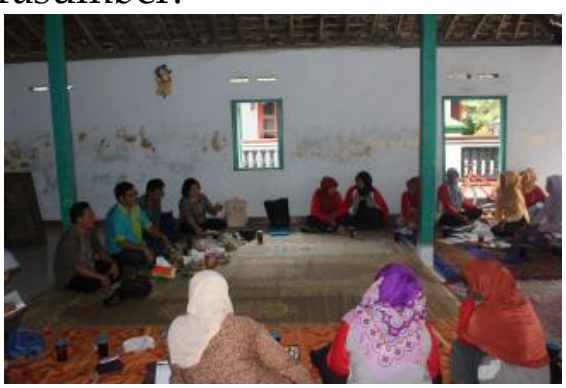

Gambar 2. Pelatihan Inclass

Pelatihan pemasaran dimaksudkan untuk meningkatkan pengetahuan mitra mengenai bagaimana cara pemasaran dengan baik. Peserta pelatihan dibekali pengetahuan mengenai penerapan sistem pemasaran bagi usaha kecil. Hal yang perlu diperhatikan dalam pemasaran diantaranya adalah kontinyuitas produksi, dan pengemasan. Selain itu disinggung pula mengenai manajemen keuangan UMKM oleh Dr. 


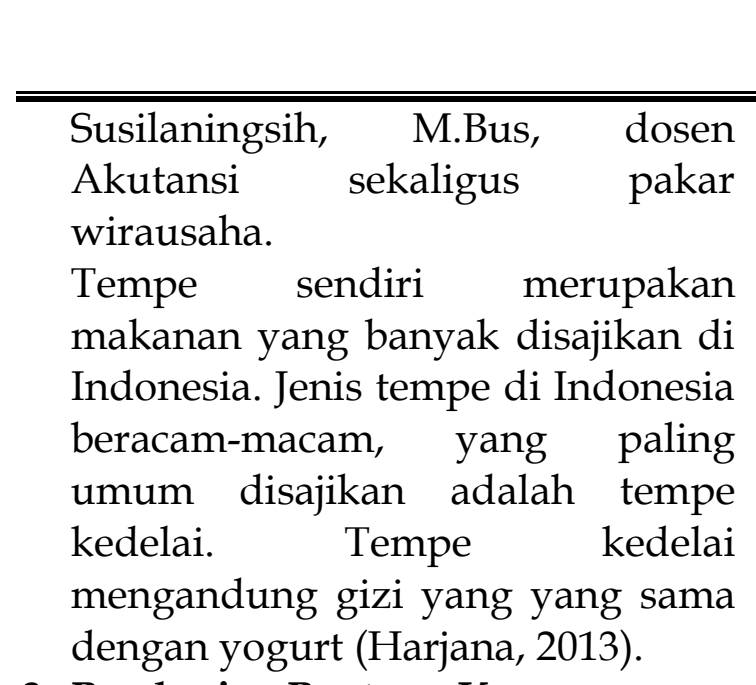

3. Pemberian Bantuan Kemasan

Kemasan keripik jamur dan keripik tempe dinilai belum layak untuk $\begin{array}{rr}\text { ISSN } & : 1979-861 X \\ \text { e-ISSN } & : 2549-1555\end{array}$

dijual secara luas. Oleh karena itu, perlu dilakukan penggantian kemasan agar nilai jual keripik tempe dan keripik jamur dapat meningkat. Kemasan awal yang digunakan adalah plastik HD yang di sealer atau di staples, saat ini kemasan telah diperbaharui menggunakan standing pouch dan sticker yang menarik. Pada produk jamu, juga dilakukan penggantian sticker dan bantuan pengadaan botol jamu.
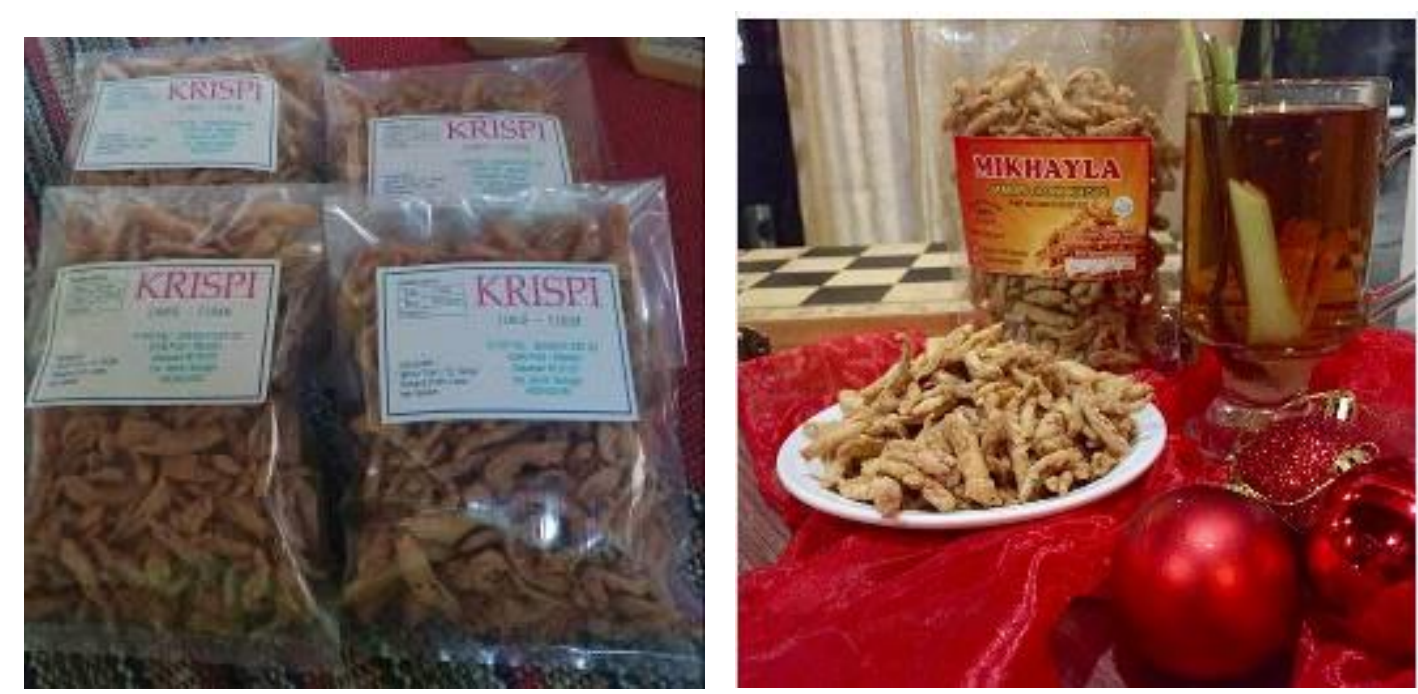

Gambar 3. Foto awal dan akhir kemasan jamur krispi
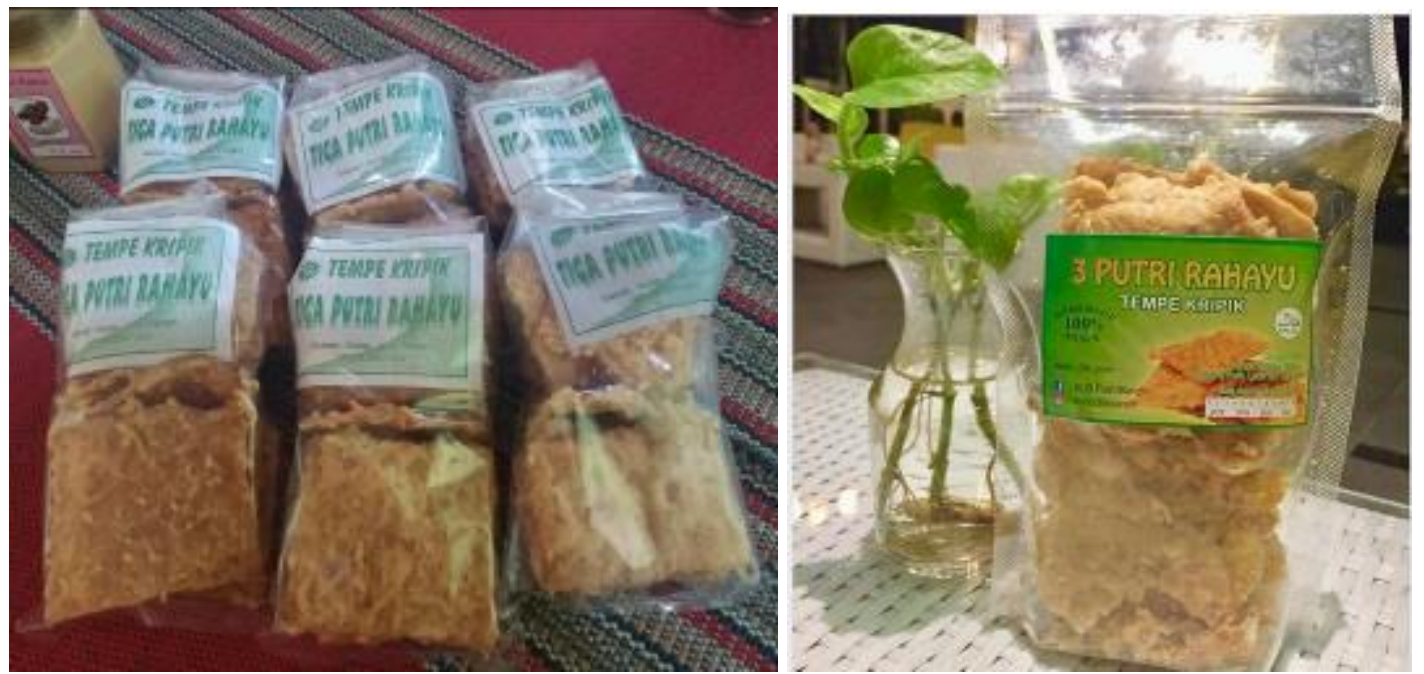

Gambar 4. Foto awal dan akhir kemasan keripik tempe 


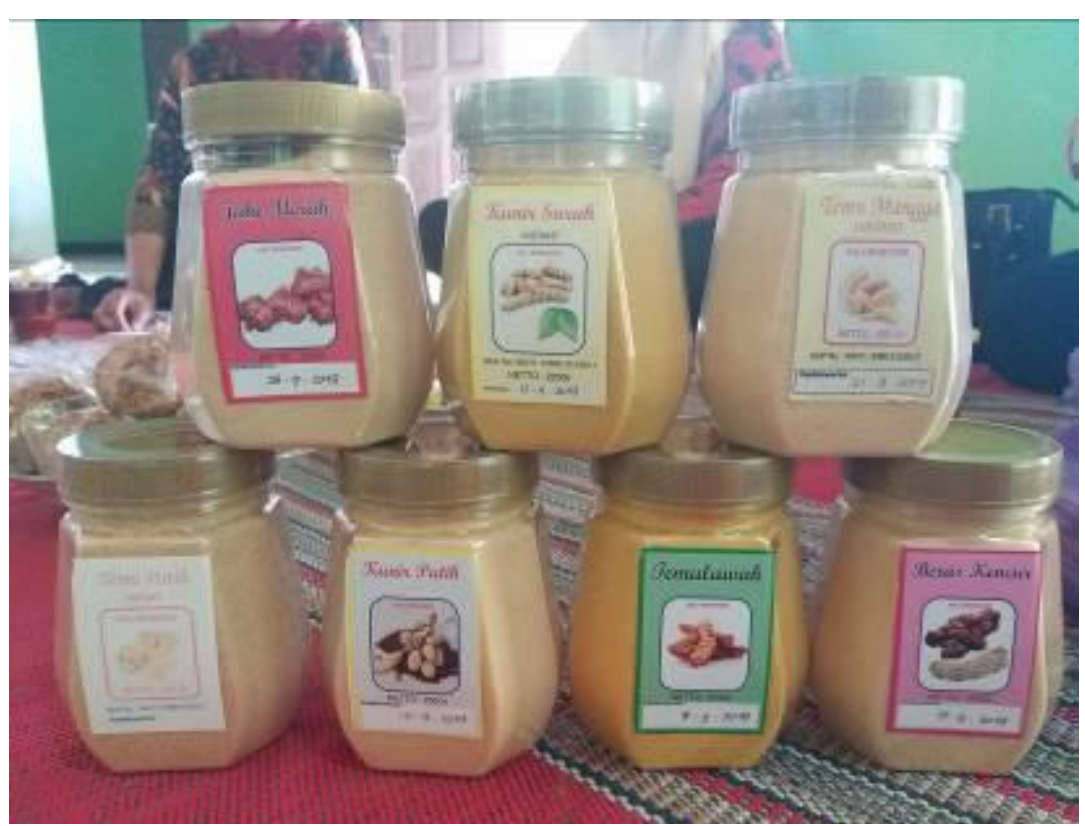

Gambar 5. Sticker awal
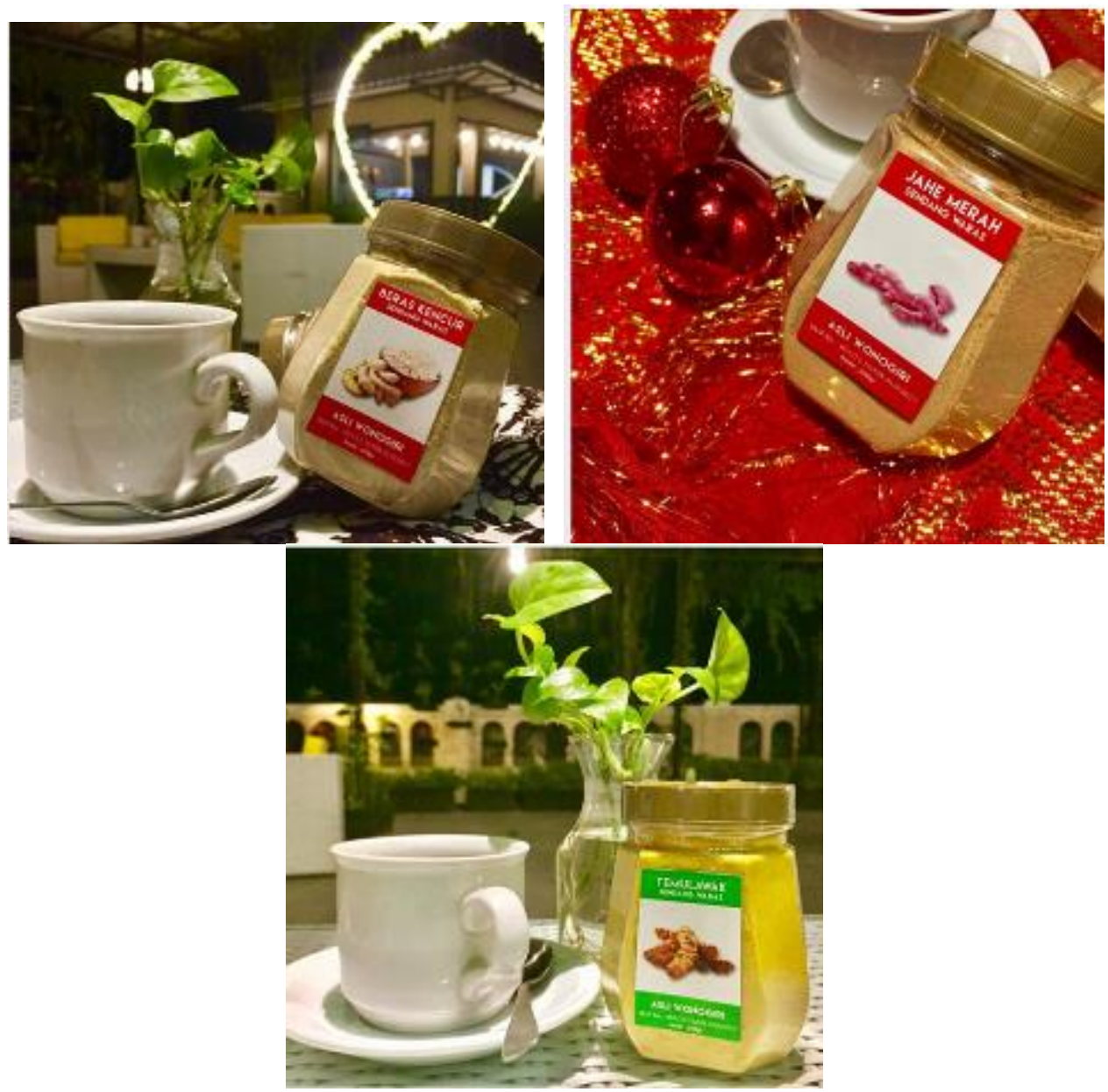

Gambar 6. Sticker setelah diperbaiki 


\section{Pelatihan Outclass}

Pelatihan Outclass dilakukan untuk meningkatkan pengetahuan mengenai aplikasi media sosial dan situs marketplace. Aplikasi media sosial yang kami perkenalkan antara lain facebook dan instagram, sedangkan situs marketplace yang kami perkenalkan adalah bukalapak.
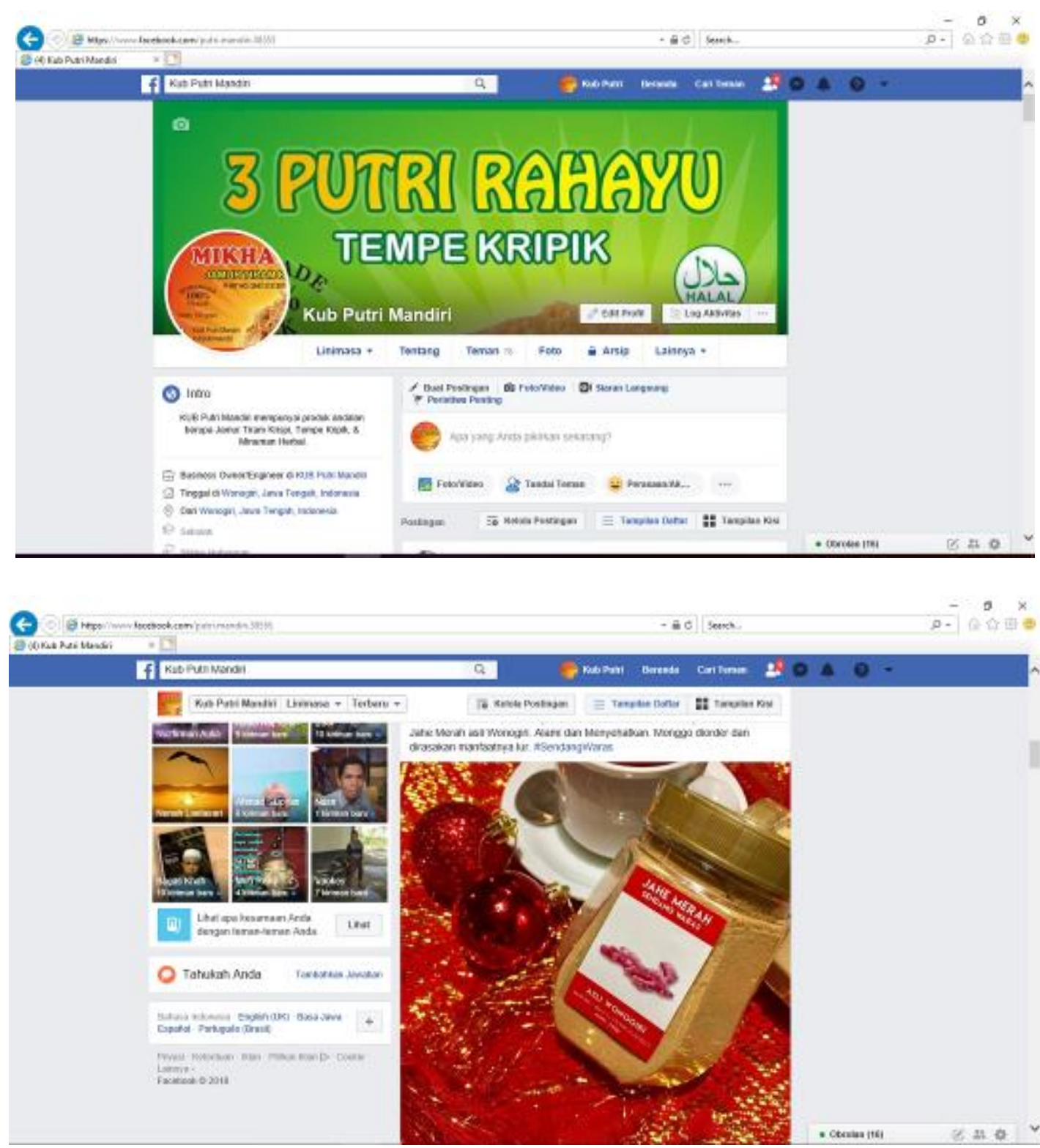


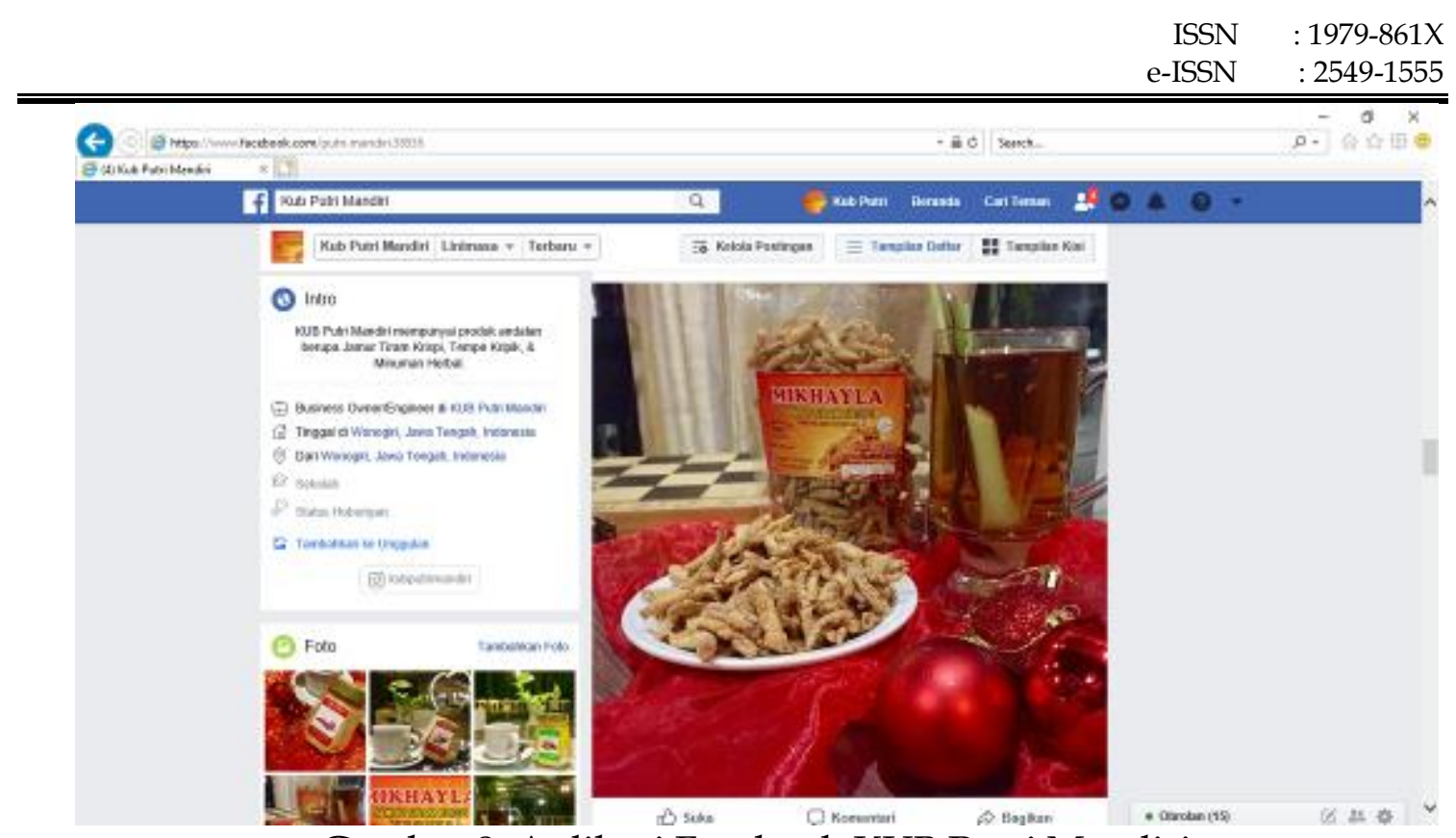

Gambar 8. Aplikasi Facebook KUB Putri Mandiri

(0) Instagram

a search

(a) $0 \stackrel{\circ}{\circ}$

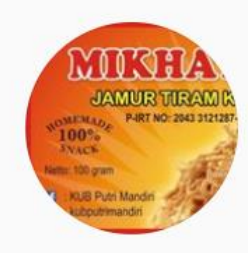

\section{kubputrimandiri follow ... \\ 9 posts 13 followers $\quad 42$ following}

KUB Putri Mandiri

KUB Putri Mandiri merupakan Kelompok Usaha Bersama lbu-lbu di Wonogiri dgn produk andalan berupa Jamur Tiram Krispi, Tempe Kripik, dan Minuman Herbal.

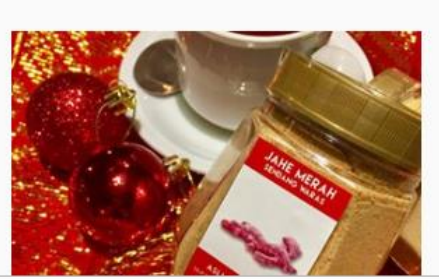

囲 POSTS (8) TAGGED
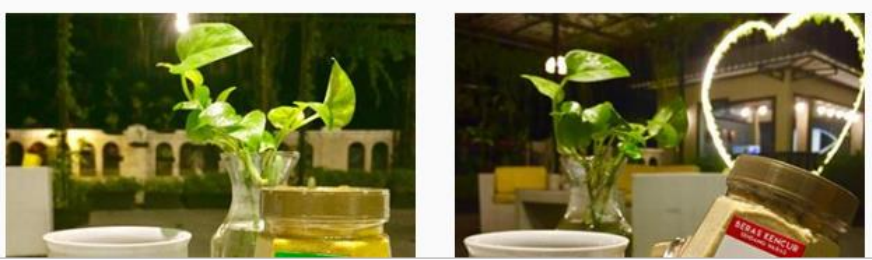

Gambar 8. Aplikasi Instagram KUB Putri Mandiri 

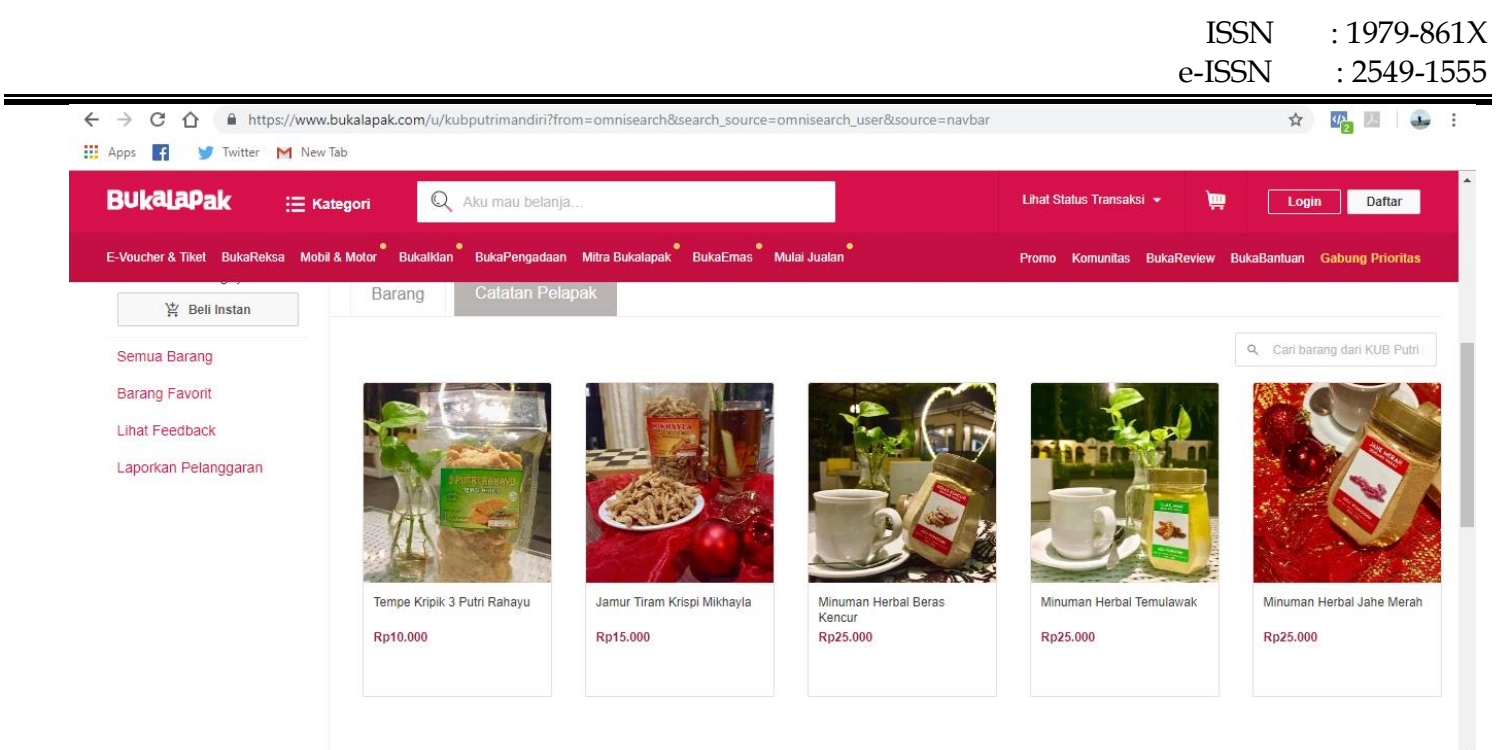

Gambar 9. Aplikasi Online Store Bukalapak KUB Putri Mandiri

\section{Pemberian Teknologi Tepat Guna}

Pemberian Teknologi Tepat Guna berupa Kamera dan Mesin Pengupas Kulit Kedelai. Kamera ini dapat digunakan untuk memotret produk-produk olahan UKM Putri Mandiri. Sedangkan mesin pengupas kulit kedelai digunakan untuk mengupas kulit ari kedelai dalam proses produksi keripik tempe. Dengan adanya bantuanbantuan dan pendampingan ini, produksi aneka olahan makanan semakin meningkat dan sudah merambah ke luar daerah Wonogiri.

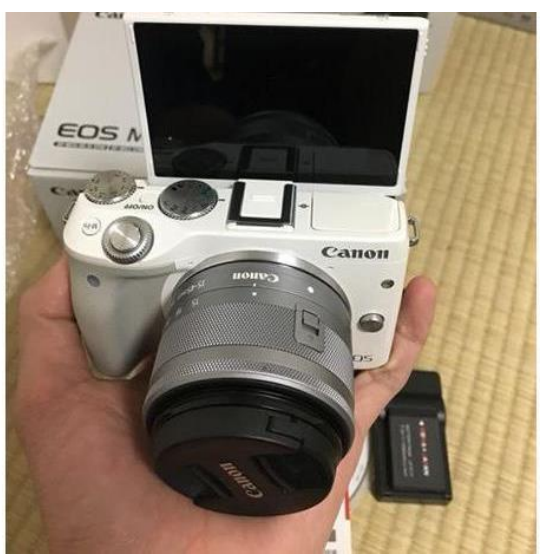

Gambar 10. Kamera untuk

Pemasaran

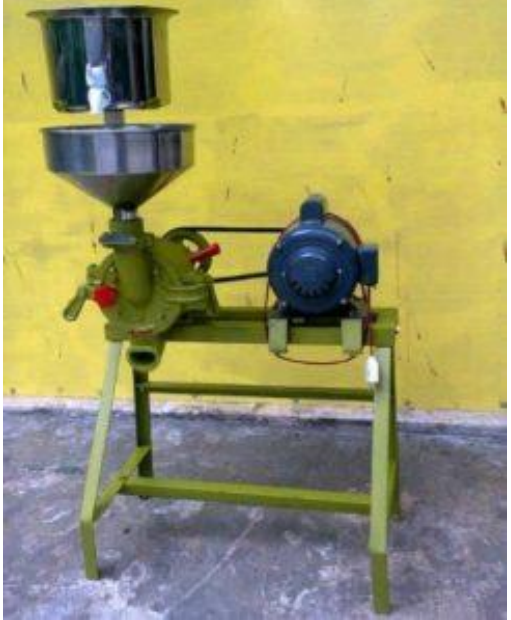

Gambar 11. Mesin Pengupas Kulit Ari Kedelai

Berdasarkan hasil pengabdian yang dilakukan oleh Sunyoto et al., 2017 serta Setyowibowo dan Prasetyo, 2017, produktivitas hasil tempe meningkat seiring dengan mulai digunakannya mesin pengupas kulit ari kedelai. Selain itu, waktu untuk memproduksi juga terangkas.

\section{KESIMPULAN}

Berdasarkan hasil dapat disimpulkan bahwa:

1. Kegiatan pendampingan yang telah dilakukan adalah koordinasi pelaksanaan kegiatan, pelatihan 
inclass, pelatihan outclass, perbaikan kemasan, pemberian bantuan berupa kamera dan mesin pemecah kulit kedelai.

2. Dengan adanya bantuan-bantuan dan pendampingan ini, produksi aneka olahan makanan semakin meningkat dan sudah merambah ke luar daerah Wonogiri.

\section{DAFTAR PUSTAKA}

Hajli, M. Nick. 2014. A Study of The Impact Social Media on Consumers. International Journal of Market Research Vol 56 Issue 3, 2014.

Harjana

D., id/2013/11/kandugan-nutrisitempe-dan-manfaatnya.html.

Setowibowo S., Prasetyo A. 2017. Pengembangan Industri Tahu dan Tempe sebagai Alternatif Pangan di Desa Curahmalang Kecamatan Rambipuji Kabupaten Jember. Jurnal Ilmiah Pengabdian Pada Masyarakat, 1(2): 11-19

Sunyoto, Sujiantoro H., Yoserizal Y., 2017. Penguatan Usaha Melalui Aplikasi Teknologi Tepat Guna bagi Kelompok Pengrajin Tempe. Jurnal Ilmiah Pengabdian Pada Masyarakat, 1 (2): 54-64. https://manfaatnyasehat.blogspot.co. 